\title{
Efektivitas musik terapi untuk meningkatkan kualitas tidur: Studi meta analisis
}

\author{
Satrio Dhiaputra Prayudi ${ }^{(1)}$, Ananta Yudiarso ${ }^{(2)}$ \\ ${ }^{(1),(2)}$ Fakultas Psikologi, Universitas Surabaya, Surabaya, Indonesia
}

\begin{abstract}
Sleep constitutes a basic need that determines human physical and psychological health, which makes identifying and examining factors that contribute to the improvement of sleep quality an important research step. To this end, this research aimed to empirically test how much music therapy has a significant effect on improving sleep quality. Using metaanalysis, we collected data from 14 international research literature reviews that involved 720 participants in total. Data were analyzed based on the mean $(M)$, standard deviation $(S D)$, and the number of participants (n). The results revealed the effectiveness of music therapy in improving sleep quality, as can be seen on the effect size hedges' $g$ of 0.89 obtained from the random-effects model with an $I^{2}$ (inconsistency) value of $94 \%$. What can be derived from this finding is that music therapy is an effective intervention technique to improve sleep quality.
\end{abstract}

Keywords: meta-analysis, music therapy, sleep quality

Tidur merupakan kebutuhan dasar yang menentukan kesehatan fisik maupun psikologis manusia, yang membuat identifikasi dan pengujian faktor-faktor yang bisa meningkat kualitasnya menjadi langkah penelitian yang penting. Penelitian ini bertujuan untuk menguji sejauh mana musik terapi berpengaruh signifikan dalam meningkatkan kualitas tidur. Menggunakan meta analisis, penelitian ini mengumpulkan data berupa 14 kajian literatur yang dipublikasikan di jurnal international yang secara keseluruhan melibatkan 720 partisipan. Data dianalisis atas dasar nilai rata-rata $(M)$, deviasi standar $(S D)$, dan jumlah partisipan $(n)$. Hasil menunjukkan efektivitas terapi musik dalam meningkatkan kualitas tidur, sebagaimana bisa diketahui atas dasar effect size hedges' $g$ yang diperoleh dari random effect model sebesar 0.89 dengan nilai $I^{2}$ (inconsistency) sebesar $94 \%$. Pemberian musik terapi dengan demikian merupakan salah satu teknik intervensi yang efektif untuk meningkatkan kualitas tidur.

Kata kunci: $\quad$ kualitas tidur, meta analisi, terapi musik

MEDIAPSI, 2021, Vol. 7(1), 53-62, DOI: https://doi.org/10.21776/ub.mps.2021.007.01.6

Received: 07-11-2020. Revised: 17-11-2021. Accepted: 21-01-2021. Published online: 24-06-2021

Handling Editor: Sumi Lestari, Universitas Brawijaya, Malang, Indonesia

*Corresponding author: Satrio Dhiaputra Prayudi, Fakultas Psikologi, Universitas Surabaya, Surabaya,

Indonesia. E-mail: s154119503@student.ubaya.ac.id

(c) (1) \&

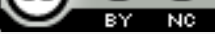

This work is licensed under a Creative Commons Attribution-NonCommercial 4.0 International License.

How to cite this article in accordance with the American Psychological Association (APA) $7^{\text {th }}$ guidelines:

Prayudi, S. D., \& Yudiarso, A. (2021). Efektivitas musik terapi untuk meningkatkan kualitas tidur: Studi meta analisis. MEDIAPSI, 7(1), 53-62. https://doi.org/10.21776/ub.mps.2021.007.01.6

\section{Pendahuluan}

Setiap manusia memiliki tuntutan dalam memenuhi sebuah kebutuhan dasar yang bertujuan dapat melangsungkan kelangsungan hidupnya. Sebuah kebutuhan dasar yang dimiliki oleh setiap individu ialah unsur-unsur yang dibutuhkan di dalam menjaga keseimbangan fisiologis yang mempunyai 
manfaat untuk mempertahankan kehidupannya dan mampu menstabilkan kesehatan dari setiap individu. Tidur adalah salah satu aspek kebutuhan dasar yang wajib dipenuhi oleh setiap manusia. Alasannya, tidur merupakan keadaan fisiologis alami yang dimiliki oleh tubuh manusia berupa penurunan kesadaran dan respon pada stimulus tubuh yang dimiliki oleh setiap manusia (Carley \& Farabi, 2016).

Kebutuhan tidur yang dibutuhkan oleh masing-masing individu sangat berbeda-beda tergantung pada kebiasaan yang sering dilakukan, pekerjaan yang dilakukan, kondisi kesehatan, dan juga tergantung pada kategori usia. Lumbantobing (2004, dalam Wicaksono dkk., 2012) menjelaskan bahwa, mengacu pada kategori usia, kualitas tidur yang baik baik individu berusia dewasa membutuhkan waktu tidur sekitar 6-9 jam, sedangkan untuk kualitas tidur yang baik pada individu berusia lanjut membutuhkan waktu tidur sekitar 5-8 jam. Menurut Wicaksono (2012), kurangnya waktu dan kualitas tidur individu mempengaruhi pembentukan sintesis protein yang memiliki peran untuk memperbarui sel dalam tubuh yang rusak.

Selanjutnya, tidur yang dimiliki oleh masing-masing individu dapat dibedakan menjadi dua jenis. Jenis tidur ini meliputi: a) jenis tidur Rapid Eye Movement (REM) sebagai tidur nyenyak yang dialami oleh individu yang juga ditandai dengan pengalaman mimpi, otot-otot menjadi rileks, dan sekresi lambung meningkat, b) jenis tidur Non Rapid Eye Movement (NREM) sebagai tidur nyaman yang dialami oleh individu yang juga ditandai dengan mimpi yang kurang, gerakan bola mata melambat, metabolisme turun, dan keadaan seluruh tubuh yang terasa rileks (Asmadi, 2008).
Pemenuhan kualitas tidur yang dialami oleh masing-masing individu memiliki ketidaksamaan. Individu dapat memiliki tidur yang berkualitas atau tidak memiliki tidur yang berkualitas, yang disebabkan oleh beberapa faktor. Menurut Asmadi (2008), tidur yang kurang berkualitas dapat disebabkan oleh faktor yang meliputi: a) kondisi kesehatan yang sedang dialami oleh masing-masing individu, b) faktor lingkungan (kebersihan, suhu ruangan, kegaduhan), c) perasaan cemas yang dapat meningkatkan hormon norepinephrine, d) konsumsi minuman yang mengandung kafein dan alkohol, serta e) kelelahan yang berlebihan.

Ada bermacam-macam bentuk penanggulangan untuk meningkatkan kualitas tidur dari setiap individu, Mengacu pada hasil dari beberapa studi klinis sebelumnya, penggunaan musik dapat mempengaruhi aspek emosi yang dimiliki oleh individu sehingga emosi individu menjadi lebih positif. Terapi musik diberikan dengan tujuan untuk memberikan sebuah pengaruh bagi munculnya emosi positif individu, yang bisa memberikan ketenangan dan mengurangi gejala stres (de Witte dkk., 2020; Rahayu, 2016).

\section{Metode}

\section{Partisipan dan desain penelitian}

Penelitian ini menggunakan sebuah kajian literatur sistematis dan menggunakan meta analisis untuk menguji efektivitas pemberian musik terapi untuk meningkatkan kualitas tidur dengan mengikuti pedoman PRISMA (Preferred Reporting. Items for Systematic Reviews and Meta-analyses; Moher dkk., 2015). Pencarian database jurnal peneliti lakukan dengan penelusuran pada Science Direct, Google Schoolar, Journal of music therapy, NCBI, Research Gate. 
Langkah selanjutnya, peneliti menyeleksi artikel jurnal terkait dengan musik terapi dan kualitas tidur dengan kriteria yang telah ditetapkan. Kriteria tersebut adalah artikel yang melaporkan effect size, yang di dalamnya terdapat kelompok kontrol dan kelompok pemberian intervensi, serta yang memiliki alat ukur yang sesuai untuk digunakan dalam penelitian ini. Dari hasil pemilahan artikel tersebut, peneliti hanya mendapatkan 14 jurnal dalam bentuk Bahasa Indonesia dan Bahasa Inggris. Berbagai kata kunci yang digunakan untuk melakukan pencarian kajian literatur yang digunakan meliputi: kualitas tidur, musik, intervensi musik, dan terapi musik. Daftar referensi kajian literatur yang ditinjau pada penelitian ini berfungsi untuk melakukan sebuah identifikasi setiap studi yang relevan.

Kriteria yang digunakan dalam penelitian meta analisis ini meliputi: 1) penggunaan a randomized controlled design, 2) keterlibatan partisipan dengan rentang usia diatas 18 tahun, 3) penggunaan musik yang dapat diaplikasikan dengan pasif untuk meningkatkan kualitas tidur.

\section{Prosedur dan pengukuran}

Hasil dari kualitas tidur pada penelitian ini dinilai menggunakan sebuah metode yang bersifat subyektif seperti menggunakan kuesioner. Penggalian data penelitian dilakukan dengan menggunakan sebuah standar sebelum mengambil data penelitian, yaitu pemberian lembar persetujuan sebelum mengikuti penelitian terkait. Data yang digali meliputi nama penulis, tahun publikasi, populasi penelitian, ukuran sampel (sample size), usia, jenis kelamin partisipan, jumlah partisipan yang terbagi dalam kelompok intervensi, sebuah metode untuk menilai kualitas tidur, dan hasil penelitian setiap partisipan yang terbagi menjadi kelompok intervensi dan kelompok kontrol.

Perbedaan rata-rata standar (standardised mean difference: SMD) pada penelitian ini digunakan sebagai ukuran efek dan hasilnya akan dinyatakan sebagai hasil SMD dengan interval kepercayaan 95\% (95\% confidence interval/Cl). Nilai SMD dapat dihitung dengan membagi perbedaan rata-rata dalam setiap kajian literatur. Untuk menghitung rata-rata tersebut, peneliti menggunakan sebuah aplikasi meta-mar untuk memudahkan peneliti mendapatkan hasil rata-rata. Nilai pada rata-rata standar (SMD) adalah sebuah indeks tanpa unit, dan hasil rata-rata tersebut bisa dibagi menjadi tiga kategori, yaitu kategori nilai kecil, kategori nilai sedang, dan kategori nilai besar. Hasil nilai rata-rata effect size yang berkisar \pm 0.2 termasuk kategori nilai kecil, sedangkan hasil nilai rata-rata yang berkisar \pm 0.5 termasuk kategori nilai sedang. Sementara itu, hasil nilai rata-rata yang berkisar \pm 0.8 termausk kategori nilai yang besar. Alur atau proses pencarian literatur disajikan dalam Gambar 1 sebagai berikut:

Gambar 1. Proses Mencari Kajian Literatur.

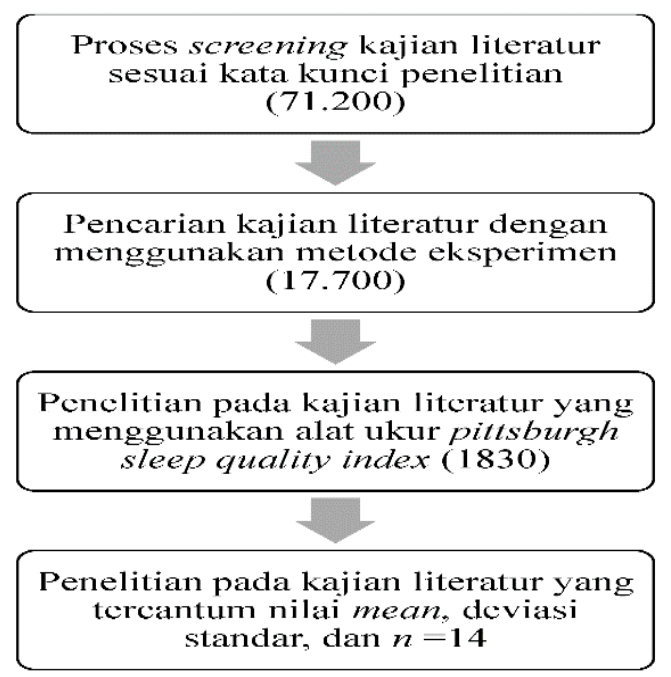


Sejumlah peneliti (Higgins dkk., 2003, 2012; White dkk., 2012) menjelaskan bahwa untuk mengetahui heterogenitas penelitian yang telah dilakukan, uji $Q$-statistic dengan tingkat signifikasi $p<0.10$ dan yang mengandung nilai $I^{2}$ bisa digunakan. Hasil nilai I-Statistic dapat menggambarkan sebuah total persentase variasi yang didapatkan pada setiap studi atau penelitian. Selanjutnya, penelitian yang menunjukkan Indeks $I^{2}>50 \%$ menunjukkan bahwa penelitian tersebut menunjukkan adanya heterogenitas.

\section{Hasil}

Kajian literatur yang dilakukan atas dasar kata kunci music dan effectiveness of music therapy to improve sleep quality, dengan waktu penelitian yang telah di publikasi dalam rentang sepuluh tahun terakhir. Pencarian kajian literatur tersebut telah menunjukkan adanya 71.200 kajian literatur yang sesuai dengan kata kunci terkait. Langkah berikutnya adalah memberikan fokus pada pencarian kajian literatur yang menunjukkan adanya metode eksperimen dengan rentang waktu sepuluh tahun terakhir, dengan tujuan mendapatkan kajian literatur yang sesuai dengan kata kunci terkait sebanyak 17.700 artikel. Peneliti kemudian melakukan kajian literatur kembali dengan menyaring kesamaan alat ukur kualitas tidur. Penyaringan ini menghasilkan 1.830 kajian literatur yang menggunakan alat ukur Pittsburgh Sleep Quality Index. Kemudian kajian literatur tersebut disaring lebih lanjut, untuk memeriksa beberapa kelengkapan komponen yang diperlukan dan untuk melakukan perhitungan ukuran efek (effect size) yang memerlukan keberadaan sejumlah parameter seperti nilai rata-rata (mean), dan jumlah sampel dari kelompok intervensi dan kelompok kontrol. Dari hasil penyaringan kajian teratur tersebut, didapatkan 14 kajian literatur yang sesuai, yaitu literatur yang menerangkan tingkat efektivitas pemberian musik terapi untuk meningkatkan kualitas tidur. Empat belas kajian literatur tersebut melibatkan 720 partisipan yang telah diidentifikasi sesuai dengan kriteria yang telah peneliti tetapkan. Pembagian partisipan tersebut mencakup 354 partisipan yang berada pada kelompok yang diberikan intervensi dan 366 partisipan yang berada pada kelompok kontrol.

Berdasarkan penelusuran yang telah dilakukan, Tabel 1 di halaman berikut menampilkan kumpulan jurnal yang menggunakan metode meta-analisis dengan mengedepankan kesesuaian variabel dan alat ukur yang digunakan. Data dalam literatur tersebut kemudian diolah dan dianalisis menggunakan aplikasi Meta-Mar versi 2.7.0 (n.d.).

Penelusuran jurnal yang diolah dengan aplikasi Meta-Mar selanjutnya menghasilkan nilai $g$ dan Seg. Langkah berikutmya, peneliti mengetahui atau mengidentifikasi hasil efektivitas dari kumpulan penelitian yang telah dilakukan yang menggunakan musik sebagai terapi untuk meningkatkan kualitas tidur dengan melihat kolom Headges'gnya. Hasil analisis tersebut ditampilkan dalam Tabel 2. 
Tabel 1. Kumpulan Hasil Analisis Kajian Literatur Menggunakan Aplikasi Meta-Mar.

\begin{tabular}{|c|c|c|c|c|}
\hline No. & $\begin{array}{l}\text { Study } \\
\text { Name }\end{array}$ & Alat ukur Intervensi & $g$ & $S E g$ \\
\hline 1 & $\begin{array}{l}\text { Chan } \\
\text { dkk. } \\
(2010)\end{array}$ & $\begin{array}{l}\text { Partisipan diberikan instrumen musik dan diminta mengisi kuesioner Pittsburgh } \\
\text { Sleep Quality Index (PSQI). }\end{array}$ & -0.28 & 0.30 \\
\hline 2 & $\begin{array}{l}\text { Chang } \\
\text { dkk. } \\
\text { (2012) }\end{array}$ & $\begin{array}{l}\text { Partisipan diberikan musik yang menenangkan dan diminta mengisi kuesioner } \\
\text { Pittsburgh Sleep Quality Index (PSQI) untuk kelompok eksperimen (KE), } \\
\text { sedangkan kelompok kontrol (KK) tidak diberikan musik. }\end{array}$ & 0.25 & 0.28 \\
\hline 3 & $\begin{array}{l}\text { Shobeiri } \\
\text { dkk. } \\
(2016)\end{array}$ & $\begin{array}{l}\text { Partisipan diberikan CD musik yang lembut untuk } 4 \text { minggu selama } 45 \text { menit } \\
\text { setiap malam dan diminta mengisi kuesioner Pittsburgh Sleep Quality Index } \\
\text { (PSQI). }\end{array}$ & -1.15 & 0.23 \\
\hline 4 & $\begin{array}{l}\text { Koenig } \\
\text { dkk. } \\
(2013)\end{array}$ & $\begin{array}{l}\text { Partisipan diberikan CD musik "lagu klasik yang menenangkan" dan diminta } \\
\text { mengisi kuesioner Pittsburgh Sleep Quality Index (PSQI) setelah } \\
\text { mendengarkan musik. }\end{array}$ & 0.00 & 0.43 \\
\hline 5 & $\begin{array}{l}\text { Shum } \\
\text { dkk. } \\
(2014)\end{array}$ & $\begin{array}{l}\text { Partisipan mendengarkan musik lembut, musik instrumental sedatif lambat } \\
\text { tanpa lirik, kira-kira } 60-80 \text { denyut per menit, berdurasi } 40 \text { menit, selama } 6 \\
\text { minggu, dan diminta mengisi kuesioner Pittsburgh Sleep Quality Index (PSQI) } \\
\text { setelah mendengarkan musik tersebut. }\end{array}$ & 1.41 & 0.28 \\
\hline 6 & $\begin{array}{l}\text { Lai \& } \\
\text { Marion } \\
(2005)\end{array}$ & $\begin{array}{l}\text { Partisipan mendengarkan kaset musik penenang selama } 6 \text { sampai } 45 \text { menit pada } \\
\text { waktu tidur selama } 3 \text { minggu, dan diminta mengisi kuesioner Pittsburgh Sleep } \\
\text { Quality Index (PSQI). }\end{array}$ & 0.97 & 0.27 \\
\hline 7 & $\begin{array}{l}\text { Vinayak } \\
\text { dkk. } \\
(2017)\end{array}$ & $\begin{array}{l}\text { Dalam terapi musik reseptif, musik pop dimainkan untuk setiap partisipan } \\
\text { dengan menggunakan pemutar MP3 (tergantung pada pilihan lagu mereka). } \\
\text { Setelah itu, mereka diminta mengisi kuesioner Pittsburgh Sleep Quality Index } \\
\text { (PSQI) untuk melihat perbedaannya. }\end{array}$ & -1.11 & 0.19 \\
\hline 8 & $\begin{array}{l}\text { Amiri } \\
\text { dkk. } \\
(2019)\end{array}$ & $\begin{array}{l}\text { Kelompok intervensi menerima } 6 \text { sesi terapi musik selama } 1 \text { jam per sesi, dan } \\
\text { diminta mengisi kuesioner Pittsburgh Sleep Quality Index (PSQI). }\end{array}$ & 0.67 & 0.37 \\
\hline 9 & $\begin{array}{l}\text { Chan } \\
(2011)\end{array}$ & $\begin{array}{l}\text { Partisipan diberikan musik yang mengalir lambat kira-kira 60-80 detak per } \\
\text { menit, masing-masing dengan durasi } 45 \text { menit, dan diminta mengisi kuesioner } \\
\text { Pittsburgh Sleep Quality Index (PSQI). }\end{array}$ & 0.29 & 0.30 \\
\hline 10 & $\begin{array}{l}\text { Jespersen } \\
\text { dan Peter } \\
\text { (2012) }\end{array}$ & $\begin{array}{l}\text { Untuk mengukur kualitas tidur, peneliti menggunakan Pittsburgh Sleep Quality } \\
\text { Index (PSQI) dan skala PTSD. Partisipan diberi pemutar musik dan } \\
\text { bantal ergonomis yang pas dengan pemutar musik. }\end{array}$ & 0.52 & 0.54 \\
\hline 11 & $\begin{array}{l}\text { Wang } \\
(2016)\end{array}$ & $\begin{array}{l}\text { Partisipan mendengarkan musik selama 30-45 menit setiap malam sebelum } \\
\text { tidur, dan diminta mengisi kuesioner Pittsburgh Sleep Quality Index (PSQI). }\end{array}$ & 0.40 & 0.25 \\
\hline 12 & $\begin{array}{l}\text { Naulia } \\
\text { dkk. } \\
(2019)\end{array}$ & $\begin{array}{l}\text { Partisipan diberikan terapi musik pada } 30-45 \text { sebelum tidur selama empat hari. } \\
\text { Kualitas tidur diukur dengan menggunakan Pittsburgh Sleep Quality Index } \\
\text { (PSQI). }\end{array}$ & 0.33 & 0.36 \\
\hline 13 & $\begin{array}{l}\text { Lafçi } \\
\text { dan } \\
\text { Öztunç } \\
(2015)\end{array}$ & $\begin{array}{l}\text { Partisipan mendengarkan musik instrumental lembut Turki (kelompok } \\
\text { eksperimen) sebelum tidur selama } 1 \text { minggu, antara pukul } 21.00 \text { dan } 01.00 \\
\text { malam. Mereka selanjutnya diberikan Pittsburgh Sleep Quality Index (PSQI) } \\
\text { yang digunakan untuk mengumpulkan data kualitas tidur. }\end{array}$ & -7.82 & 0.76 \\
\hline 14 & $\begin{array}{l}\text { Laily } \\
\text { dkk. } \\
(2015)\end{array}$ & $\begin{array}{l}\text { Partisipan diberikan sebuah terapi musik instrument, dan selanjutnya diminta } \\
\text { mengisi kuesioner Pittsburgh Sleep Quality Index (PSQI) untuk mengukur } \\
\text { kualitas tidur mereka. }\end{array}$ & -3.37 & 0.57 \\
\hline
\end{tabular}

Keterangan. $g=$ effect size hedges' $g$, SEg = standard error effect size hedges' $g$. 
Tabel 2. Hasil Analisis Ukuran Efek (Effect Size).

\begin{tabular}{ccccccc}
\hline Model & $\begin{array}{c}\text { Headges'g } \\
(S M D)\end{array}$ & $S E g$ & $95 \% \mathrm{Cl}$ & $z$ & $p$ & Heterogeneity \\
\hline $\begin{array}{c}\text { Fixed } \\
\text { effect }\end{array}$ & 0.51 & 0.08 & {$[0.35,0.67]$} & 6.33 & $<.001$ & $I^{2}=94 \%, \chi^{2}=212.97, d f=$ \\
& & & & & 13 \\
$\begin{array}{c}\text { Random } \\
\text { effect }\end{array}$ & 0.89 & 0.34 & {$[0.22,1.55]$} & 2.62 & .009 & $94 \%$, \\
& & & & & $T^{2}=1.45$ \\
\hline
\end{tabular}

Keterangan. $S E g=$ standard error effect size hedges' $g, \mathrm{CI}=$ interval konfidensi, $z=$ skor $z, p=$ nilai signifikansi, $\chi^{2}=$ nilai chi-square, $d f=$ derajat bebas, $T=$ nilau Tau.

\section{Diskusi}

Hasil analisis yang tertera pada Tabel 1 menunjukkan sebuah perhitungan menggunakan analisis effect size yang terdiri dari partisipan kelompok eksperimen dan kelompok kontrol. Dari hasil pada tabel ini, nilai effect size yang dapat digunakan pada random effect model ialah 0.89 (dengan $95 \%$ $\mathrm{Cl}=0.22$ sampai dengan 1.55 , dan nilai $p=$ .009), dengan nilai $I^{2}$ sebesar 94\%. Dengan nilai yang didapatkan tersebut, musik terapi memiliki large effect size dalam menanggulangi kualitas tidur yang bisa dilihat dari hasil nilai $I^{2}$ (inconsistency) yang lebih besar dari 80 persen dan nilai effect size yang lebih besar dari 0.8. Implikasi dari hasil-hasil tersebut, nilai dari Hedges $g$ (SMD) random effect model bisa digunakan dalam metaanalisis. Borenstein dkk. (2009) menjelaskan bahwa random effect model memberikan hasil yang lebih reliabel, dan tujuan dari penggunaan model random effect biasanya untuk menggeneralisasikan atau membentuk simpulan umum dari beberapa penelitian kajian literatur yang terkait.
Berdasarkan dari hasil proses metaanalisis tersebut, pemberian musik terapi bisa disimpulkan berpengaruh efektif untuk meningkatkan kualitas tidur. Kemudian menurut Im dan Lee (2014), pemberian musik dapat berdampak pada aspek psikologis orang tua. Selain itu, Sihvonen dkk. (2014) menyatakan bahwa pemberian musik juga dapat membangkitkan respon psikofisiologis dengan mempengaruhi sistem limbik pada tubuh individu tersebut sehingga bisa menimbulkan perasaan yang tenang. Hal tersebut terjadi karena didapatkan sebuah fakta bahwa persepsi musik mengarah pada pengadukan pengalaman emosional. Pengalaman ini merupakan indikasi bahwa sistem limbik terlibat dalam pemrosesan rangsangan dari musik, serta bahwa sistem limbik yang terlibat tersebut dipengaruhi oleh nada dan irama musik.

Selanjutnya, Chang dkk. menyatakan bahwa temuan penelitian mereka berkontribusi pada pengetahuan yang ada tentang efektivitas musik sebagai terapi untuk meningkatkan kualitas tidur orang dewasa penderita insomnia. Selain itu, dengan 
mendengarkan musik berjenis slow pada saat tidur di malam hari, individu dapat meningkatkan istirahat mereka ke arah yang lebih baik dan dapat merasakan tidur REM yang berkepanjangan. Selaras dengan temuan tersebut, Shobeiri dkk. (2016) menemukan adanya perbedaan yang signifikan kualitas tidur antara kelompok eksperimen dan kontrol setelah intervensi, dan mereka menyimpulkan pemberian musik terap efektif meningkatkan kualitas tidur.

Pemberian musik dalam meningkatkan kualitas tidur yang dimiliki oleh masingmasing individu dari penelitian terdahulu menggunakan beberapa jenis musik. Hal tersebut bisa dicermati pada penelitian yang dilakukan oleh Amri dkk. (2019) yang menggunakan jenis musik tradisional asal Persia. Pada penelitian tersebut, mereka melakukan studi untuk pertama kalinya menggunakan jenis musik tradisional asal Persia untuk menangani subjek pria yang memiliki gangguan tidur (insomnia). Hasil penelitian mereka menunjukkan bahwa terapi music tradisional berpengaruh signifikan untuk menangani gangguan tidur (insomnia) dan untuk meningkatkan kualitas tidur pada subyek yang berada pada kelompok eksperimen.

Selaras dengan temuan-temuan penelitian di atas, riset Jespersen dkk. (2012) menggunakan suara yang ditimbulkan dari alat musik klasik seperti piano, harpa, gitar, oboe dan cello. Alat musik klasik tersebut dipadukan dengan suara-suara alam seperti suara kicauan burung dan suara ombak. Dalam penelitin mereka, partisipan yang berada pada kelompok intervensi diminta mendengarkan musik-musik klasik tersebut dengan tujuan untuk menenangkan, menghilangkan stres, menstimulasi indera imajinasi, dan meningkatkan kualitas tidur.
Hasil penelitian ini menunjukkan bahwa paparan jenis-jenis musik tersebut berperan signifikan dalam meningkatkan kualitas tidur partisipan.

\section{Kesimpulan}

Temuan dalam penelitian ini memberikan dua implikasi. Pertama, musik bisa diaplikasikan sebagai strategi peningkatan kualitas tidur yang berperan bagi kesehatan mental maupun fisik. Kedua, aplikasi musik sebagai intervensi untuk meningkatkan kualitas tidur, meskipun demikian, harus diterapkan tidak secara sembarang, dengan mempertimbangkan kemunginan bahwa tidak semua jenis musik berperan efektif meningkatkan kualitas tidur pada indivdu dalam semua rentang usia dan individu dengan berbagai macam latarbelakang sosial dan budaya.

\section{Daftar Pustaka}

Amiri, S., Parvizi Fard, A., Khaledi-Paveh, B., Foroughi, A., Bavafa, A., Bazani, M., ... \& Sadeghi, K. (2019). The effectiveness of music therapy on insomnia using Persian traditional music. Journal of Kermanshah University of Medical Sciences, 23(2), Article e86914. https://doi.org/10.5812/jkums.86914

Asmadi. (2008). Konsep dasar keperawatan. EGC.

Borenstein, M., Hedges, L. V., Higgins, J. P., \& Rothstein, H. R. (2021). Introduction to meta-analysis. John Wiley \& Sons.

Carley, D. W., \& Farabi, S. S. (2016). Physiology of sleep. Diabetes Spectrum, 29(1), 5-9. https://doi.org/10.2337/diaspect.29.1.5 
Chan, M. F. (2011). A randomised controlled study of the effects of music on sleep quality in older people. Journal of Clinical Nursing, 20(7-8), 979-987. https://doi.org/10.1111/j.1365-

2702.2010.03368.x

Chan, M. F., Chan, E. A., \& Mok, E. (2010). Effects of music on depression and sleep quality in elderly people: A randomised controlled trial. Complementary Therapies in Medicine, 18(3-4), 150-159. https://doi.org/10.1016/j.ctim.2010.02. 004

Chang, E. T., Lai, H. L., Chen, P. W., Hsieh, Y. M., \& Lee, L. H. (2012). The effects of music on the sleep quality of adults with chronic insomnia using evidence from polysomnographic and self-reported analysis: A randomized control trial. International Journal of Nursing Studies, 49(8), 921930. https://doi.org/10.1016/j.ijnurstu. 2012.02.019

de Witte, M., Spruit, A., van Hooren, S., Moonen, X., \& Stams, G. J. (2020). Effects of music interventions on stress-related outcomes: A systematic review and two meta-analyses. Health Psychology Review, 14(2), 294-324. https://doi.org/10.1080/17437199.201 9.1627897

Ellis, P. D. (2010). The essential guide to effect size: Statistical power, metaanalysis, and interpretation of research result. Cambridge University Press.

Higgins, J. P. T., Jackson, D., Barrett, J. K., Lu, G., Ades, A. E., \& White, I. R. (2012). Consistency and inconsistency in network meta-analysis: Concepts and models for multi-arm studies. Research
Synthesis Methods, 3(2), 98-110. https://doi.org/10.1002/jrsm.1044

Higgins, J. P., Thompson, S. G., Deeks, J. J., \& Altman, D. G. (2003). Measuring inconsistency in metaanalyses. Bmj, 327(7414), 557-560. https://doi.org/10.1136/bmj.327.7414.5 57

Im, M. L., \& Lee, J. I. (2014). Effects of art and music therapy on depression and cognitive function of the elderly. Technology and Health Care, 22(3), 453-458. http://doi.org/10.3233/THC-140803

Jespersen, K.V., \& Peter, V. (2012). The effect of relaxation music listening on sleep quality in traumatized refugees: A pilot study. Journal of Music Therapy, 49(2), 205229. https://doi.org/10.1093/jmt/49.2.2 05

Koenig, J., Jarczok, M. N., Warth, M., Harmat, L., Hesse, N., Jespersen, K. V., ... \& Hillecke, T. K. (2013). Music listening has no positive or negative effects on sleep quality of normal sleepers: Results of a randomized controlled trial. Nordic Journal of Music Therapy,22(3), 233-242. https://doi.org/10.1080/08098131.201 3.783095

Lafçi, D., \& Öztunç, G. (2015). The effect of music on the sleep quality of breast cancer patients. International Journal of Caring Sciences, 8(3), 633640. http://internationaljournalofcarin gsciences.org/docs/14_Laftci_original _8_3.pdf

Lai, H. L., \& Good, M. (2006). Music improves sleep quality in older adults. Journal of Advanced Nursing, 53(1), 134-144. 
https://doi.org/10.1111/j.1365-

2648.2006.03693.x

Laily, E. I., Juanita, J., \& Siregar, C. T. (2015). Efektifitas pemberian terapi musik instrument terhadap kualitas tidur pasien gagal ginjal kronik yang menjalani hemodialisa. Idea Nursing Journal, 6(3), https://doi.org/10.52199/inj.v6i3.6790

Meta-Mar. (n.d.). Meta-Mar (Version 2.7.0)

[Internet software]. https://www.metamar.com/

Moher, D., Shamseer, L., Clarke, M., Ghersi, D., Liberati, A., Petticrew, M., ... \& Stewart, L. A. (2015). Preferred reporting items for systematic review and meta-analysis protocols (PRISMA-P) 2015 statement. Systematic Reviews, 4(1), 1-9. https://doi.org/10.1186/2046-4053-4-1

Naulia, R. P., Allenidekania, A., \& Hayati, H. (2019). The effect of music therapy on sleep quality among children with chronic illness. International Journal of Nursing and Health Services (IJNHS), 2(1), https://doi.org/10.35654/ijnhs.v2i1.51

Rahayu, C. S. (2016). Efektivitas terapi musik instrumental gitar dalam menurunkan kecemasan matematika bagi siswa kelas VIII A SMP Pangudi Luhur 1 Klaten pada materi sistem persamaan linier dua variabel (Skripsi, Universitas Sanata Dharma). http://repository.usd.ac.id/12421/2/11 1414014_full.pdf

Shobeiri, F., Khaledi, S., Masoumi, S. Z., \& Roshanaei, G. (2016). The effect of music therapy counseling on sleep quality in pregnant women. Int $\mathrm{J}$ Med Res Health Sci, 5(9), 408-416. https://www.ijmrhs.com/medical- research/the-effect-of-music-therapycounseling-on-sleep-quality-inpregnant-women.pdf

Shum, A., Beverly, J. T., Jeff, T., \& Moon, F. C. (2014). The effects of sedative music on sleep quality of older community-dwelling adults in Singapore. Complementary Therapies in Medicine, 22(1), 49-56. https://doi.org/10.1016/j.ctim.2013.11. 003

Sihvonen, A. J., Leo, V., Särkämö, T., \& Soinila, S. (2014). Effectiveness of music in brain rehabilitation. A systematic review. Duodecim; Laaketieteellinen

Aikakauskirja, 130(18), 1852-1860. https://pubmed.ncbi.nlm.nih.gov/25558 $627 /$

Vinayak, S., Dehkhoda, F., \& Vinayak, R. (2017). The effect of music therapy on sleep quality of cancer patients undergoing chemotherapy or radiotherapy: A randomized control trial. Journal of Social Sciences (COES\&RJ-JSS), 6(4), 734-743. https://doi.org/10.25255/jss.2017.6.4.7 34.743

Wang, Q., Chair, S. Y., Wong, E. M. L., \& Li, X. (2016). The effects of music intervention on sleep quality in community-dwelling elderly. The Journal of Alternative and Complementary Medicine, 22(7), 576584.

https://doi.org/10.1089/acm.2015.030 4

White, I. R., Barrett, J. K., Jackson, D., \& Higgins, J. P. (2012). Consistency and inconsistency in network meta-analysis: model estimation using multivariate meta-regression. Research Synthesis 
Methods, 3(2), 111-125.

https://doi.org/10.1002/jrsm.1045

Wicaksono, D. W. (2012). Analisis faktor dominan yang berhubungan dengan kualitas tidur pada mahasiswa Fakultas Keperawatan Universitas Airlangga. Fundamental and Management Nursing Journal, 1(1), 46-58. http://doi.org/10.20473/fmnj.v1i1.1213 1 